\title{
1 \\ Rembrandt, or the portrait as encounter
}

\section{Didier Maleuvre}

'A good painter', says Leonardo da Vinci, 'is to paint two main things, namely man and the workings of man's mind. The first is easy, the second difficult'. ${ }^{1}$ As portraiture came into its own during the Renaissance, it became accepted that a good likeness alone does not make a portrait. The able painter must convey, besides mood and affect, a sense of who the sitter is: their personality and, deeper still, the sense of what it is like to exist as this person. In other words, portraiture is a matter not just of aesthetic proficiency but also of moral and psychological attunement. But how does the painter step into the sitter's subjectivity? How does s/he paint acknowledgement? It seems the artist here must depart from the familiar province of seeming and enter the unmarked domain of being - a puzzling transition if we consider that art traditionally pairs with imagination and makebelieve.

In this essay, I argue that imagination isn't an impediment to moral perception. In fact, imaginative depiction plays a crucial role in apprehending others as persons. I develop this line of argument by reflecting on a key feature of portraiture: likeness. Likeness is normally understood to be a property of a person's appearance; but it is also

1 Leonardo da Vinci, Notebooks, London, Oxford Classics, 1980, p. 168. 
clear that, by definition, likeness refers to a model of comparison beyond appearance proper. A person doesn't look like herself- this is a tautology; she looks like the image of herself we mentally draw for her. At first blush a portrait presents the likeness of a person; on consideration this likeness cannot pre-exist the portrait. Thus portraiture is essential to having a likeness, of looking like oneself.

Of interest here is that likeness shifts from the singular to the plural, from the personal to the interpersonal. My likeness relies on another person's creative witnessing. How does the intersubjective nature of likeness inform portrait painting? How, in particular, does the painter represent their commitment to offering the gift of likeness (which is ultimately the gift of personhood) to their sitter? I examine this question through a selective discussion of portrait paintings of Rembrandt, paying special attention to those instances where likeness breaks down for the sake of, paradoxically, preserving the uniqueness of the represented person.

\section{I}

It is no use trying to hide the elephant in the room - not an elephant this size. Rembrandt cuts an anachronistic figure in a volume of essays addressing portraiture in the digital age. Next to digital photography, facial-recognition software and web imagery, Rembrandt is bound to look a tad passé. Yet anachronism is far from being the subject of this essay. For nothing about a Rembrandt portrait is out of date; nothing in what I propose to convey about Rembrandt is indifferent to our present circumstances. The time of the portrait, I want to show, is now - the now of encounter, the now of the human conversation. And this moment, this now, is the beating heart of great portraiture.

This idea that an excellent portrait radiates personal presence is actually rather uncontroversial outside of academia. Hopefully, the experience I propose to describe isn't foreign to even the gimlet-eyed connoisseur. Wandering through a picture gallery, your eye grazes on seascapes and genre scenes, gods and queens, crucifixions, abductions, rapture and woe, a repentant Magdalene, a defiantly murderous Judith, a congress of happy shepherds. From the corner of your eye you wearily spot a portrait. You lumber up to it. You gaze. 
Then it happens. Suddenly, or perhaps slowly, but surely unawares, you are drawn into a hypnotic face-to-face. The walls melt away, the shuffling crowd vanishes, the world becomes background and you are alone in the presence, no longer of a picture, but of a face, a person-a person who wants something from you. At last you shake yourself free of the spell. You readjust your gaze: once again it is just a picture you are looking at. And yet it has become much more. The portrait seems to hold the presence, the aura, the heft (there is no right word for it) of a real person. Though it falls short of the real person, in another sense it feels like too much of one. His or her demand on our attention feels unconditional, agonisingly more pressing than the real presences we allow to intrude into our everyday attention. We seem to have had an 'encounter' - a word, and an experience, on which we will want to cast light.

Not that this encounter is unusual. In fact, the subject of Rembrandt's human realism is, rather, a commonplace of art history. But to say that it is commonplace doesn't mean there is anything ordinary about it or that it has been properly looked into. One might even say it has been easier to dismiss, for there is something about the achingly pressing presence of a Rembrandt portrait that outstrips the remit of art historians. It seems to call on the joint counsel of psychologists, philosophers, spiritual teachers and saints. It asks for our reckoning, but reckoning isn't the business of art criticism. Whereas the art critic will often privately admit the bliss of an encounter, professional training, academic discourse and the distinctions of art history journals do not really make room for the language to describe it. Specialised and technical to a fault, the language of criticism is inimical to the 'subjective' haze of encounter.

Rather than emotions and intimations, the professional critic prefers facts, among which, certifiably, is the artefact. Of one thing the learned critic is sure, a painting is a thing. For all its likeness to a person, a portrait is an image, and images don't speak, see or feel. To forget this is to wander off into a magic forest where statues walk and plaster Madonnas weep. But representations are first and foremost facsimiles. However we dig into them we will find pigments and oil and canvas and the imaginary reconstruction of an artist. The hard kernel of reality is out of the picture. Any attempt to recover it is sentimental indulgence; it belongs in the bottom drawer of criticism known as the pathetic fallacy, the mistake of attributing an emotion to the object 
that evokes it rather than the person who feels it. In sum, if you want a real person, go to a singles' bar, not a museum, and by all means stop trying to have encounters with dry old paint. ${ }^{2}$

In search of scientific facts, art criticism latches onto the social and material context of art. Rembrandt scholars invite us to focus on the conditions of workshop production, the buying and selling of pictures, public taste - indeed any contextual element that helps bury the fact that for three months a human being sat before another, the first to offer their likeness, the second to ponder and recreate it in paint. You may call this portrait a Rembrandt, says the critic, but it is really 'market conditions', 'stylistic conventions' and 'set programmes' that created the paintings. ${ }^{3}$ But, of course, this is a will o' the wisp-and most unscientific to boot. Abstractions like 'the market' or 'public taste' do not make pictures. Men and women do. Indeed, to dismiss this plain fact is to commit a pathetic fallacy, and on balance it is probably more scientific to believe in weeping icons than historical abstractions that paint. Of course it is not my intention to lead us to forget that an image isn't what it represents. I am, however, going to look at the person inside the portrait to see what lies at the bottom of this naive encounter. Is it a misapprehension? If so, is it pathetic and perverse, or benign and necessary?

II

Some conceptual work is in order if we are to develop the discussion further. In essence, I want to show that looking at a portrait and seeing a face aren't dissimilar actions. To see the face as a person is to see the portrait in it. My hunch is that the realism we naively maintain at the portrait gallery is the same naive realism that allows us to see one another as persons and not things.

2 TJ Clark, The site of death: An experiment in art writing, New Haven, Yale University Press, 2008; James Elkins, Pictures and tears: A history of people who have cried in front of paintings, London, Routledge, 2004.

3 Chief among the anti-psychological school of portrait criticism, see Ernst van de Wetering, 'The multiple functions of Rembrandt's self portraits', in Christopher White and Quentin Buvelot (eds), Rembrandt by himself, London, National Gallery, 1999; H-J. Raupp, Selbstbildnisse und Künstlerporträts von Lucas van Leyden bis Anton Raphael Mengs, Brunswick, Herzog Anton Ulrich-Museum, 1980. 


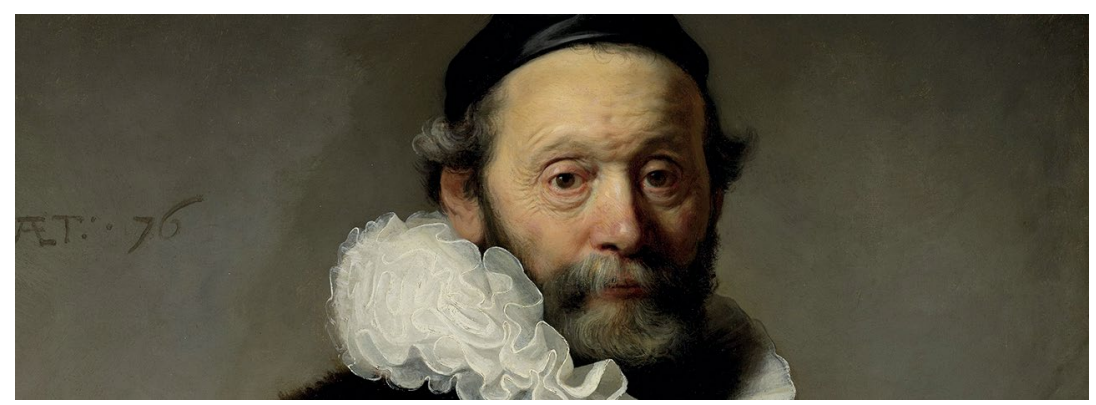

Figure 1.1: Portrait of Johannes Wtenbogaert (detail), Rembrandt Harmensz. van Rijn, 1633, 130 x $103 \mathrm{~cm}$.

Source: Rijksmuseum, Amsterdam, public domain images.

A portrait, we are told, is a thing. This is quite true, but empirically speaking a face too is a thing - ridges and dips and holes tied to muscle attachments. It is realist naivety - our sympathetic tendency to project form, intention, sense and feeling - that transforms those ridges and holes into a face. Unless we imagine into its surface, unless we take it as manifesting consciousness, a face is a hunk of flesh. Our everyday approach to the human face is, in a restrictive sense, aesthetic: it draws the material data into a portrait, and believes in it. ${ }^{4}$

Infants are precocious portrait-makers when they interpret the blur of eye-mouth-cheek-nose as mother's face. ${ }^{5}$ And when young children begin drawing, they start by squiggling faces. Representation starts spontaneously as portraiture. And this isn't because a face is a quaint and interesting circle. Rather children draw a circle because they see a face in it, and drawing it allows them to enact the transfer from mind to mother. We begin our toddler-doodler career as naive realists. We do not depict in order to cover up or look away from human reality but to relate to it through other means. On this score, to insist that a portrait is just a system of paint smears is like the sinister pedantry that would consist in teaching a child to say not 'this is mum', but 'this is a shower of photons bouncing off a face, hitting my optic nerve

4 On the subject of subjective projection see James Elkins, The object stares back: On the nature of seeing, New York, Harvest Books, 1997.

5 See John Willats, Making sense of children's drawings, Mahwah, New Jersey, Lawrence Elbaurm, 2005; Georges-Henri Luquet, Children's drawing, London, Free Association Books, 2001 [1927]. 
and forming into a mental pattern that denotes another object called mum'. In everyday life we elaborate portraits of each other; we see the face as figuring forth a human being.

This is not to deny that the human brain somehow gets tricked into projecting personality into a two-dimensional facsimile; it is to insist that this sort of emphatic naive projection quickens the normal process of seeing actual faces. My worry is that when critics deny the person in the portrait they undermine the representational thinking that sustains ordinary moral intelligence - the intelligence that allows us to imagine constructively the life of others and behold the face as a portraying-forth. Now this is all very well, but a portrait is a thing, and the face quite another. The former we hang on the wall; the latter we hang not, or else only to punish. But let us look again into the distinction between face and portrait. Our ways of speaking often betray us, and in this instance reveal that the difference isn't a hard-and-fast one.

Of both a portrait and a face we say that they present a likeness. This, we say pointing at a photograph, is a likeness of Winston Churchill, and we thereby designate an object. But we also use the word 'likeness' in another sense; for instance, when we say 'this photograph captures Sir Winston's likeness' or 'Sir Winston and Sir Randolph, his son, share a likeness'. We can also say a likeness binds the young, middleaged, and elderly Winstons. In these instances we are referring not to an artefact but to an abstraction. This abstraction is no fancy conceit; it is how we identify a person. To recognise Winston Churchill is to check his face against an enduring likeness - a likeness that exists independently of Winston since, as we have seen, Randolph also has a claim to it. Does young Winston look like old Winston, or is it old Winston who looks like his younger self? Randolph looks like Winston, but this is because Winston looks like Randolph. The point is that a likeness doesn't really belong to the person proper. But, then, to whom does it belong?

The observer, of course, and our ability to make a mental portrait out of the living person. All in all, and so far as we recognise one another, we are the artists of each other's likeness. This, we are beginning to see, has an interesting bearing on personal identity. For if identity 
assumes being identical to oneself, and if such similarity is construed by an observer, then identity will surely involve a strong interpersonal element. It takes at least two persons to look like oneself.

Let's summarise this way: first, a mug becomes a human face insofar as we mentally portray it; second, identity is conditional on recognition; and third, recognition requires the imaginative projection of a portrait onto the face.

III

Let's now carry these abstractions back to the painter's studio. At the heart of Rembrandt's art-I think this is true of all great portrait painters - is an insight into the commonality between being and being depicted; between, if you will, identity and portraiture. The person in the portrait says, 'I am here because I have been seen. I exist because I have been painstakingly acknowledged to exist'. And this statement is no less true outside the portrait gallery. There, too, someone's humanising gaze of others is needed to actuate your or my personhood.

The idea that others give us our humanity doesn't sit well with our culture's individualistic ethos. We, the children of Descartes, Locke and Kant, tend to believe in spontaneously autonomous personal identity. Public and private, me and others: this distinction is integral to the modern psyche. The self is a private fiefdom. When the ' $I$ ' presents that fiefdom to the world it is always with the sense of putting up a public relations pageant. For the true self is what one deeply is, never what one shows. Hence our propensity to suspect the touch-up job, the slick lie, in portraiture. We cannot help assuming that whatever the intention, a portrait holds a mask over the face. The painter, we say, could only show what the sitter seemed, not who they are.

There are several reasons why this is not true, at least not true of great portraiture such as Rembrandt's. Let's begin with the historical reason. The clear-cut duality of private self and public persona, or, if you will, face and portrait, doesn't travel well across the ages. Admittedly the sixteenth and seventeenth centuries did see a trend towards more individualised experience. Castiglione, Montaigne, Cervantes, Shakespeare and Descartes - their works are the milestones 
of a growing sense of separation between the private self and public life. Until quite recently, however, these were more philosophical exercises than realities. Actual everyday life mostly went on as it had for centuries, woven into an intricately communal web. If Shakespeare did 'invent' the deep modern self, this invention took place on the rowdily public London stage - hardly a solitary affair. Even the protoindividualist Hamlet needs an audience, and a performance of his individuality, to get at who he is privately. He doesn't know himself until he acts out his various social selves. Of course he worries about being honest and true to himself. The problem is that there is no 'himself' until he acts before a public.

This was also Rembrandt's world - a gregariously civic milieu in which very few people would have fretted about the division between their 'true' selves and their social selves. It would scarcely have occurred to them to consider the gaze of others a Trojan horse. Little would they have understood Sartre's Cartesian trepidations about the objectifying glance of others. Seventeenth-century man was an unquestioning public creature. To be and to be seen, to be and to be portrayed wasn't the feuding pair it has become in the modern age of privacy.

If anything, the golden age of Dutch society would have deepened the social embedding of selfhood. Released from feudal vassalage, men and women had to negotiate their lives and livelihoods, their good names and fortunes, in teeming urban environments. Not fixed ancestry but trade and burghers' councils and influence-peddling defined who one was. A drawback of merchant society, aristocrats bemoaned, was that no one was ever relieved of having to prove their worth. No step up the social ladder was secure. The work of garnering social relevance was never finished. ${ }^{6}$ Identity was a fungible asset, always in need of recognition and reaffirmation. It was, we might say, permanently on the auction block.

This fragility is the context of Rembrandt's portraiture. It explains the expectant attention of his faces, their susceptibility to slight, their pained need of confirmation. These were the faces of people who lived by the esteem of others. They are the faces of men and women taking part in the strange new experiment of having their portraits painted,

6 See Jonathan Israel, The Dutch Republic: Its rise, greatness, and fall, 1477-1806, London, Clarendon Press pp. 328-32, 344-53. 
a luxury formerly the perk of princes and prelates. Their parents had been commoners, invisible and unpaintable. Suddenly they were sitting in front of a painter's easel, like gawky provincials in Sunday dress - though dress, when it comes to it, was not something you could hide inside because clothes were generally plain and uniform in Calvinist Amsterdam. Sumptuary laws frowned on the wearing of insignia, frippery and showy signs of distinction. One's good name was one's face, bare and uncovered, and this is what Rembrandt looked at, alive to his sitters' expectant mood, which sometimes bespeaks utter vulnerability. The faces he painted look for a witness: for someone with whom they can put themselves in trust.

Very often Rembrandt's portrait commissions were of merchants (the shipbuilder Jan Rijksen, the fur merchant Nicolaes Ruts, the cloth merchant Maerton Looten), men whose livelihoods depended on social exchange and thus on trust, negotiation and reputation (the part of our own self we do not own). Hence the implicit aim of these portraits: to present a face that says to investors, bankers, underwriters and society at large, 'you can trust me', 'your investment is safe with me', 'give me your guilders and I will repay you tenfold'.

Rembrandt discovers, or at any rate chronicles, what happens to the human face in the bourgeois age - the age that made human identity ever so much more fragile, more conditional and more contingent than it had been under the feudal caste system. Under feudalism, in an age of virtually non-existent social mobility, identity was mostly an innate non-negotiable asset, high or low, which fortune, better known as Divine Providence, allocated at birth to the individual. One was born a peasant or a great lord, a laborator or a bellator, and no amount of striving could turn the former into the latter (not, at any rate, within one lifetime). Enforcing this rigid, one-time allocation of identity was the work of theocratic ideology, which remitted the matter of personhood to divine ordinance, laying bare the contents of one's psyche to God's omniscient and omnipresent eye. Why discuss, debate, argue, doubt or explore the contents of one's soul when all is decreed and defined by the ultimate Judge above? The question of personal identity was, as it were, out of one's hands and, crucially, out of other people's hands as well. Without straying too far into the sociology of the transformation from agrarian feudalism to the mercantile, citybased economy of the nascent modern period, it is well-known that the economic and social experiment first started in the Italian city 
states of the Renaissance and then more clearly emerged in Flanders, Holland and the cities of the Hanseatic League, together with ordered trade, manufacture and banking, and the political administration of industrial prosperity. ${ }^{7}$ With urban mercantilism came social mobility and therefore a more fluid, contingent and change-prone experience of personal identity. No longer was identity a fixed allocation. It was a movable and negotiable asset, a currency subject to the upward and downward re-evaluations of good and bad luck (for this reason the allegoric figure of Fortuna re-emerges during the Renaissance), and subject also to the contingencies of personal success or failure, and consequent civic standing. In sum, identity in the bourgeois economy of incipiently modern Europe had a much more fragile, vulnerable, fungible quality. As society moved from the Court to the Town, identity came to depend on ongoing exchange with equals, competitors, fellow guildsmen, associates, customers, fellow traders and neighbours. Acknowledgement was given, but like all things given could be taken back or refused. We see in the mercantile city just how much identity rested on the currency of one's good name, one's reputation: that is, through the recognition of others.

The contrast between the fixity of pre-bourgeois identity and a contingent bourgeois experience of identity is best seen when we consider the court portraiture of the Cinquecento of a painter like Bronzino against Rembrandt's civic portraiture of mercantile Amsterdam. The high gloss and immaculate finish of a Bronzino portrait, such as the portrait of Eleonora of Toledo, Grand Duchess of Tuscany, conveys but one thing: that the creature before us is a kind of immaculata conceptio of identity. Bronzino doesn't delve into the inner springs of personality; he maintains the mystique of aristocratic status, its aloofness, the idea that a great lord is not made but born. The Duchess's subjectivity doesn't wait on our testimony. Nor does it wear on contact or leak. It is decay-proof. Certainly it isn't liable to downward reappraisal. For this reason no grand duchess of Tuscany ever asked a Rembrandt to do her portrait. She who thrives on ignoring the gaze of the awestruck many - this person wants not a Rembrandt but a court artist; the Bronzino of the Medici court or the David of Napoleonic glory, an artist who can rustle up the stainless gloss

7 Fernand Braudel, Civilization and capitalism, 15th-18th century, Vol. 1: The structures of everyday life, New York, Harper \& Row, 1981, esp. pp. 479-525. 
of a bulletproof face. Sensitive portraits of tyrants are few because tyrants freeze the person-to-person encounter that begets intimate portraiture: Elizabeth I is a jewel-box, Louis XIV a minotaur, Stalin a poster idol. Court portraiture conveyed all this by holding forth a miracle of synthesis: not a visible brushstroke betrays its making, its workshop provenance.

This contrasts sharply with Dutch portraiture. Unlike its Italianate cousin, a portrait by Rembrandt or Frans Hals doesn't conceal its layered, analytic, obviously manufactured construction. It isn't just that Dutch portraiture doesn't airbrush the corrugations of time and the material genealogy of the individual's flesh. It's that the portraitist flaunts their brushstrokes (thick, streaky, laboured), which tell of industry. The strenuous hand admits that these burghers, far from being born into an identity, made themselves who they are. In life as in paint, they are made of contingency.

Social identity in the bourgeois age is work-in-progress. Unlike the Duchess, a Dutch burgher cannot take recognition for granted. Eleonora of Toledo's identity is an awesome fait accompli. The Dutch merchant who sits for his portrait, by contrast, calls on our recognition; his likeness has an expectant, other-directed quality, conveyed by the deliberately tentative, cumulative brushwork. The latter tells us that identity is a mutually constructed thing. Both sitter and painter have to work at it. Identity is interaction, that is, artefact, and it is achingly alive to the confirming look of others. See me, the Rembrandt face says. See me and ponder me, because without you I am not sure. Here identity awaits confirmation. Thus the contrast between aristocratic and bourgeois portraiture, Italian and Dutch, Court and Town comes to this: while a Bronzino records a pre-existing face; Rembrandt recommends a face to our attention, knowing that this face exists only so far as this recommendation and this attention last.

Where caste and religion prevail, the painter isn't invited to puzzle out the sitter's personality, the facial chiaroscuro of seeing and being seen. The painter doesn't need to plumb the silence of a human face because there is no silence. God knows everything, down to the lees of one's mortal soul. This certainty siphons off facial depth and mystery. The faces of the theological-aristocratic age are those of people who know they cannot stop being who they are. If they do pose, their posing comes naturally. One might say that it hides nothing. 
First, because nothing is ever hidden (from God); second, because no amount of inner idiosyncrasy, of internal twistedness, can dint the iron of caste identity (a mad king is king nonetheless); and third, because the divide between public and private, the outer and the inner, isn't the antinomy that it would become post-Reformation. This homogeneity of identity helps to explain the mostly flat, hieratic style of portraiture that prevailed until the mercantile revolution of the late fifteenth and sixteenth centuries. Until then a portrait tended to be a symbol, an icon, a cameo, generally cold to psychological probing. It is in the mercantile city-states of Italy, then of Northern Europe that, not coincidentally, portraiture evolves towards a less hieratic style. In the late 1400s, the portrait turns sideways: neither frontal, nor profile, but in-between; half in light, half in shade, a limbo between revelation and mystery. Henceforth, particularly in Rembrandt, when the subject does strike a grand pose it is with a self-undercutting hint of irony; sometimes of parody.

Rembrandt indeed learned from Italianate portraiture, and parodied its forms (Rembrandt sitting himself in the fur and velvet of a Raphael grandee). Art historians regard these portraits as parodic or aspirational - Rembrandt, the son of a country miller and a baker's daughter, either clawing his way into the dream-life of a Florentine prince or mocking its pretensions. ${ }^{8}$ Whether aspiration or political lampoon, we cannot for this reason take his self-portraits, at any rate those of the middle period, as straightforward invitations to a one-to-one with the artist. A great deal of window-dressing has gone into them. Less so in the portraits of the late period, when Rembrandt's bourgeois fortune began to turn, and creditors took away his furniture, and his standing among the Amsterdam bourgeoisie began to totter; when, indeed, he became an economic failure. Gone then is the parodic intent, the aesthetic commentary on his Italian predecessors, the insider's joke or political theatre. ${ }^{9}$ From then on his self-portraits are more a plea for recognition, that most precious of bourgeois commodities, especially for the bourgeois loser, which, socially speaking, is what Rembrandt became in his last, sad decade. In these self-portraits Rembrandt takes in the full fact of his inner and outer contingency, depicting himself with the same earnestness,

8 Mariet Westermann, Rembrandt, London, Phaidon, 2000, pp. 153-7.

9 Harry Berger Jr, Fictions of the pose: Rembrandt against the Italian Renaissance, Stanford, Stanford University Press, 2000, pp. 427-514. 
sensibility and earnest recognition he had given his sitters in the best portraits. Rembrandt is undeniably in dialogue with other painters, in particular with Rubens and the Italians. As such he is in dialogue with art's history, forms and ideas. But his attention isn't merely theoretical, and the subject of his paintings isn't just other paintings. Standing at the easel, Rembrandt is also in dialogue with people - his sitters, his relations, his own person, to whom he owes the currency of bourgeois life: that is, acknowledgement, the gift of biography.

The personalism of Rembrandt's portraiture is, first of all, a byproduct of a great social experiment: the sea change that was the relative equality of social conditions or, if not equality, at least the breachability of conditions - the fact that social status was now open to new entrants (and also produced outgoing losers). This levelling of human identity (no longer an immutable, God-appointed fixture but a permeable process, an economic variable) is essential to the experience of the portrait-as-encounter. It must be remembered that Dutch painters, whether Rubens, Jan de Bray, Frans Hals, Vermeer, Pieter de Hooch, Gerrit Dou, Jan Steen or Rembrandt, all hailed from the merchant middle class, sometimes from the stratum of artisans and small traders - the same middle class that by and large was the subject of their portraiture. This means that when Rembrandt stood at the easel he did not face princely creatures stratospherically above his own station. He saw fellow beings who competed in the marketplace of social acknowledgement like he did. And like him, the burgomaster sitter wasn't a mythical projection of the grovelling crowd; he was above all a fellow citizen paying another to depict him - that is, to be seen, acknowledged, portrayed. This is no simple service, for if the customer's power lies in his fee, the artist holds the spiritual power of recognition. And when it comes to portraying his fellow townsmen and women, Rembrandt doesn't do satire or sentimentality, and he certainly doesn't do adoration. He does civic acknowledgement, which he knows is the mysterious quantity by which he, good bourgeois that he is, lives. So he renders the russet frizz of the man's beard, the sympathetic crow's feet around the eye, the embossing of midlife on the cheek as though each detail were a talisman, the concentrate of an entire life. A person stands forth: not a curiosity, not a facet of everyday life, but a person, a person like oneself, one might say, except 
that oneself, as Rembrandt acknowledged in his self-portraiture, is far from being an open-and-shut case. It requires abysmal attention: literally, a taste for the abyss.

Civic equality (not to mention the Christian equality of souls) enabled the portrait-as-encounter. Which is why, at least to my eye, Rembrandt isn't quite as adept at giving women their full subjectivity. Either lust or a gender barrier or prejudice (we cannot venture to say which) blurs the mirror. He certainly is a better observer of matrons; the younger or more desirable the female, the more he tends to confabulate. It is a creature of fancy Rembrandt paints in the portraits of his beloved Saskia, and for all their hint of intimacy, we feel ourselves being set up to ogle and daydream. Rembrandt is known to paint women in profile, but no man does he ever sit in profile. A profile tends to be much more of a stylised synthesis. In any case it isn't something one has to face. One doesn't have to stare into those eyes. For this reason a profile is easily abducted by abstraction.

Fanciful avoidance also has the better of Rembrandt when he turns to group portraits. The fantastical masquerade that is The night watch suggests that he fell for the musketeer mystique. Here he stops looking; he confabulates. We admire the brilliance; address ourselves to the separate person, however, we cannot. Likewise, his pictures of the patriciate of aristocratic young bloods, whom he depicts as soft-focus apparitions, eyes and bodies sidling into some romantic unknown. It is cases like these that, from a position much lower down the social ladder, Rembrandt delivers social mystique as commissioned, with creatures delicately airbrushed out of everyday life. This is Rembrandt at his most Italianate. ${ }^{10}$ And for a moment, as with an aristocratic portrait by Titian, we feel the cold whiff of unshakable self-certainty, and of what it is like to exist beneath the notice of people to whom one does not, and could never, matter. The aristocrat of the Baroque courts had his portrait drawn not to solicit public attention but to confirm that all eyes were on him even before he cared to look down. The bourgeois who is Rembrandt's subject secures social acknowledgement through the portrait. And social acknowledgement (negotiable, contingent, conditional) is what Rembrandt cannot help distil into his own, especially late, self-portraits.

10 On the topic of Rembrandt and Italian art, see Kenneth Clark, Rembrandt and the Italian Renaissance, New York, New York University Press, 1966; and Berger, 2000. 
Compare Titian's Portrait of a man and Rembrandt's admiring tribute to the Venetian master, Self-portrait leaning on a stone sill. For all Rembrandt's admiration of Titian, he seems not to grasp what makes the latter's portrait so terrifyingly beautiful: its aristocratic disdain. Titian's man doesn't need us to carry on in his magnificent, lip-curled existence. He sees us before we see him, and doesn't find the prospect rewarding. We are an off-glance in his day. Rembrandt's face is another story: it quavers with alertness. Wrinkle-browed, the hint of a bite on his lips, his gaze seared into ours, he is nothing if not determined to catch our eye. He may look dashing under the cocked beret, but the flurried cross-hatching, the crackling frizz of hair, the static bristles of his sleeve all prickle with intent, the lines at dry point crisscrossing his figure in a fever of attention-getting, the strain of which finally tells in the fatigued dimming of his eyes. Or take Raphael's Portrait of Castiglione and Rembrandt's homage: Platonic poise and dreaminess on Raphael's side; on Rembrandt's a man who buttonholes our attention lest he cease to exist should we look away. Castiglione exists before and after the portrait; Rembrandt, precariously, through the portrait.

\section{IV}

The idea that the bourgeois self exists through the portrait allows us to revisit another commonplace of portrait criticism. Earlier I betrayed dissatisfaction with some blind spots of materialist criticism. But this isn't to say at all that subjective-emotive art criticism has all the right answers. One of its core assumptions is that a portrait records a preexisting personality; that it serves as a personal mirror. 'A private dialogue, a lonely old man communicating with himself while he painted', is how one critic explains Rembrandt's late self-portraits. ${ }^{11}$ This idea is both obvious and untrue.

First of all, a portrait is much more than a channel of communication; it is an act of creation. A mirror relays a pre-existing likeness, whereas a portrait creates one. Moreover as intimate and personal as a self-portrait may be, it is never a 'private dialogue'. There is little about a portrait that is merely inward or private. Painting is a hands-on activity that generates a concrete artefact. In the work

11 Manuel Gasser, Self-portraits from the fifteenth century to the present day, New York, Appleton Century, 1963, pp. 90-1. 
of art the subjective objectifies itself, and the inner becomes outer. Self-portraiture secretly wants an audience; it asks a public to ratify from the outside who one takes oneself to be on the inside. This way of cultivating external forms throws into doubt the notion of some internally looped personal self.

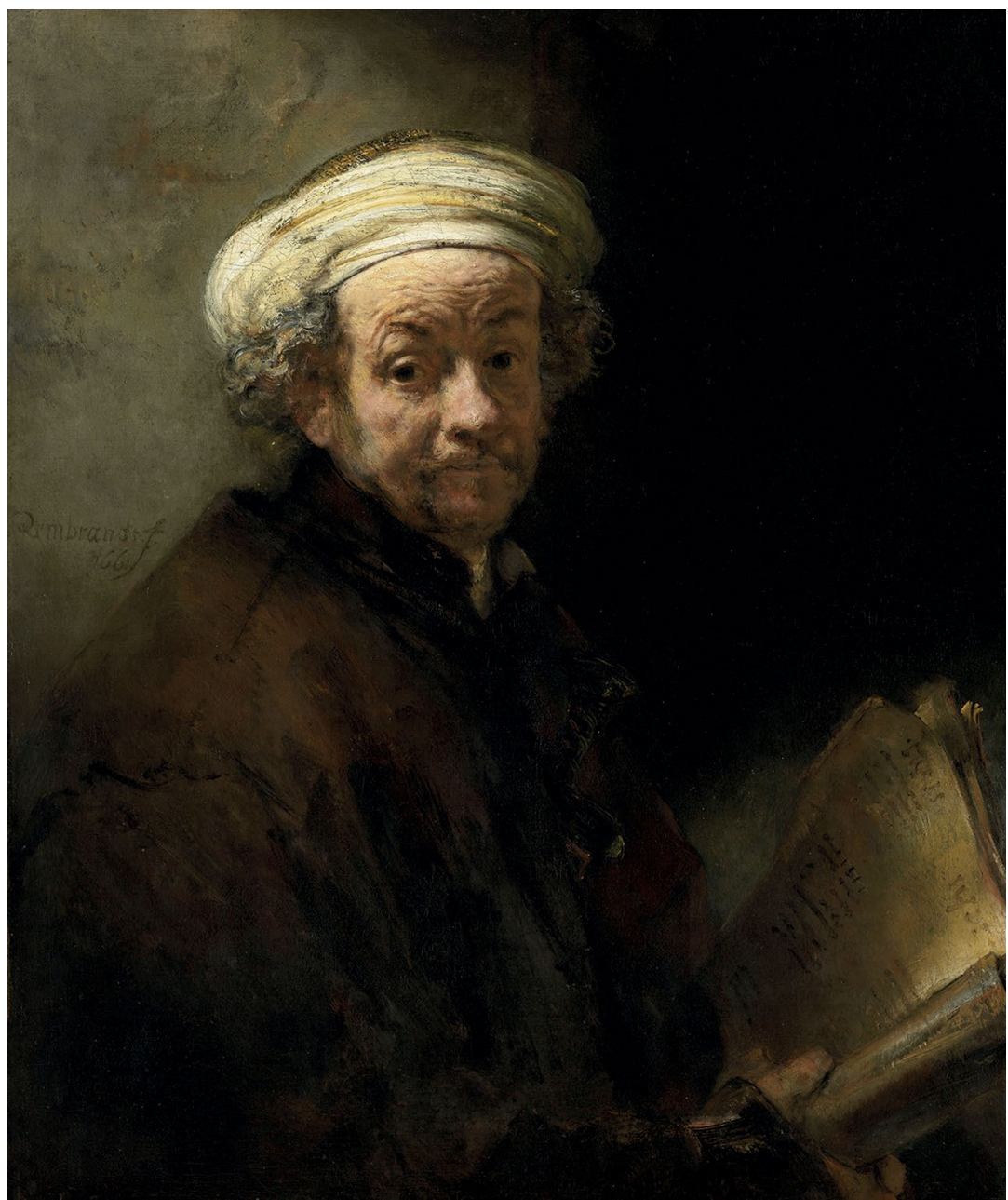

Figure 1.2: Self-portrait as the Apostle Paul, Rembrandt Harmensz. van Rijn, 1661, oil on canvas, $91 \times 77 \mathrm{~cm}$.

Source: Rijksmuseum, Amsterdam, public domain images. 
Far from being inward, a self-portrait requires a painter to adopt an external viewpoint. The artist depicts himself not by looking inward but by looking at what other people see. Self-depiction here is filled with the acknowledgement of other people's gaze. It is a confession about the ghostliness of the so-called inner self. Had Rembrandt possessed perfect self-transparency, it is unlikely he would have returned again and again to the mirror over his seventy-eight selfportraits. Rembrandt wasn't himself until he painted himself. And more than a means to construct an identity, self-portraiture was internal to his sense of self. It was just what it felt like to be Rembrandt. ${ }^{12}$

There is a hint of this in his working method. Not for Rembrandt the job of merely capturing his own likeness. The stakes were higher: it was a matter of finding himself. As a pupil described, Rembrandt never began a portrait by contouring or defining his general features but rather by 'violent, flurried strokes ... Painting by means of these strokes, he worked so slowly, and completed his things with a tardiness and toil never equalled by anybody' ${ }^{13}$ Rembrandt didn't 'block' the face and then fill it in. He didn't have a theoretic overview of a likeness; human presence was something he needed to paint his way into, layering and moulding one brushstroke at a time, building towards a climax of recognition that came, or not, at the end of three months, often more, a delay not every Amsterdam patron was willing to endure, which is perhaps why Rembrandt so frequently turned to the long-suffering mirror. Rembrandt worked ad hoc, resisting the easy lure of summarily sizing up the sitter. Hence the iterative paint strokes, the clotted, glutinous, lumpy texture of his surfaces, particularly of the late period. They are of faces travelled through, explored, delved into. Above all, they are incorporate faces, heavy with mortal flesh, with ageing and physicality. We can see the welts of paint laid on, one after the other. We feel the toil, and the duration of making enters the portrait and time becomes one of its dimensions. These searching, overlapping strokes are like a process of approaching; they ask permission for ingress. They are the work of acquaintance. They acknowledge the perfectible, never perfected labour of adjusting

12 See Alpers' discussion of Rembrandt portraiture as theatre in Svetlana Alpers, Rembrandt's enterprise: The studio and the market, Chicago, Chicago University Press, 1998, pp. 34-6. This analysis supports my intuition that unless it is portrayed, a face remains abstract. But then the aesthetic mode isn't theatre; it makes real people more real.

13 Joachim von Sandrart, Filippo Baldinucci and Arnold Houbraken, Lives of Rembrandt, London, Pallas Athene, 2008, p. 23. 
to a reality that is more commanding and elusive than painting itself, though it requires painting to come into its own. That reality is the face - civic bourgeois identity in the flesh.

This long, drawn-out painterly labour is a lesson to us whose idea of portraiture is irremediably tainted by photography. Today, in the vast majority of cases, portraiture means snapping a picture. And photography doesn't go much for the soft-footed work of acquaintance. The camera is a hunter, not an interlocutor. It 'catches' or 'captures' a moment. It snaps and snags. Photography is an aesthetic of shoplifting, not of confession. It is also a rhetoric of extreme reduction for it crams the vast and fluid presence that is a human being into a split second snatched out of the air. It purports to trap the human form of life in a quantum. Think of the crushingly vacant eye of Hal 9000, the supercomputer villain in Stanley Kubrick's 2001: A space odyssey. Here the aesthetic of soul snatching meets the aesthetic of murder. Hal records without seeing, and this is why murder comes so easily to it.

As for the human eye itself, it doesn't see in 1/500th-of-a-second brackets. Cutting into life, a photograph shows what no one actually ever sees. Its nature is forensic, and its use archival. A portrait, for this very reason, it cannot yield since it cannot describe and doesn't wait on a face. It doesn't have the active patience to suffer a reality to emerge. And without the creative patience that is description, without the labour of seeing one's way around the landscape of a face, the human face is but a wan abstraction, a graph, a marker-this independently of how true to life its record may be.

Perceiving the abstract nature of photography depends on whether we remain alive to the danger against which Rembrandt is warningthe danger of distraction. Rembrandt's romance of the face reminds us that our existence hangs on each other's gaze. We are humans thanks to the moral work of mutual depiction. Nothing is so common as to dismiss a face as a thing or a type. Nothing is so tempting as casualness, especially in our photographic, televisual culture, where offhand attention is a style - the 'cool' cat, the slacker who 'chills', the Facebook selfie flashing the orthodontically standardised grin that makes one look like a photograph even before the picture is taken (there is such an undertow of conformity in our scramble for personal recognition). 
Real portraiture is the opposite of casualness. To portray is an act of looking-at that is also a looking-after. It makes a face matter. It may be informal but it is never casual. And because it is not casual, its products are never generic. A photograph cannot care because a camera lens cannot see what it records. And no matter how great or intelligent or kind a photographer is, he or she cannot force the camera to care. This is why a good portrait photograph is good in spite of being a photograph; it is good by virtue of being lucky-because the button was pushed at the right moment.

Take, for example, the world-famous 1984 photograph of the emeraldeyed Afghan girl also known as the 'Afghan Mona Lisa'. The moniker alone speaks volumes about how little we think of portraiture, or how little we expect of each other. As photography goes it is a striking picture of a strikingly beautiful face framed by a Holbeingreen backdrop and a cinnamon headscarf. If the picture is beautiful, however, it is because the girl is beautiful. Photojournalist Steve McCurry was a lucky man with the right equipment. But his skills were of a technical not moral nature. He may well be a big-hearted human being; but the point is big-heartedness is not required to produce a great photo of a face. A photographer doesn't need to be especially attentive, patient, responsive or committed. In principle there is no reason why the 'Afghan Mona Lisa' couldn't be the work of a sociopath. We wouldn't know the difference.

By contrast, imagine a portraitist who is narrow-eyed, cruel, callous, shifty, incurious, absent-minded: their pictures are likely to be caricatures, mangled nightmares - the gropings of soul-blindness. A psychopath can presumably make a good mathematician, perhaps a piano virtuoso, a master of systems; to be a good portraitist it takes an artist who, when at the easel, is morally awake.

Late twentieth-century portraiture is alive to the moral vacancy of photography. Andy Warhol turned out reams of photo-painted portraits that are really an elegy to portraiture: bleached and flattened facial logos that are more trademarks than persons. How quickly has mass-processed photography leached the lifeblood out of a face. Warhol makes portraits of persons who are never truly seen, only recognised - congealed in the formaldehyde of fame, crudely outlined and daubed in the neon glare of instantaneous mass recognition: cognition without encounter. Your face, my face: who has time to 
notice? The camera lens does it for us. Truly the camera has cheapened the human face, taking the labour (of love) out of it. What took months for Rembrandt to reckon with, the lens shutter dispatches in a trice.

And there is a price to pay for efficiency. The camera's indifference wears hard on the face. There hangs over it the glassy reminder that in between the eye and the sitter there stood a recording device implacably devoid of concern, sociopathically casual. Warhol's masochistic charm, we might say, consists in showing what happens to the human face when we allow ourselves to be recorded without being depicted. We revert to flesh, or its postmodern equivalent, plastic (think of Jeff Koon's embalming treatment of Michael Jackson, or Pierre and Gilles' cryogenically candied faces).

Genuinely depicted flesh, by contrast, is never just flesh. Rembrandt's famous painting of the flayed ox shows a carcass, which though dead is anything but lifeless. In fact, you might say it isn't dead enough. Whatever we depict as dead is understood to have lost its life. And whatever lacks life is not lifeless. For what lacks spirit by definition ails, is bereft, is soulful - is as throbbingly soulful as that carcass that still screams for the life wrenched out of it. Nothing that is truly depicted is ever lifeless. If meat could not be dead stuff to Rembrandt's eye, then how much less a human face?

The novelist Jean Genet disagrees. He argues that Rembrandt's late self-portraits proclaim a painter who 'had to recognize himself as a man of flesh - of flesh? - rather of meat, of hash, of blood, of tears, of sweat, of shit, of intelligence, of other things too, ad infinitum ${ }^{\prime}{ }^{14}$ Actually this statement disproves itself (at least with respect to blood, tears and sweat). To recognise oneself as meat assumes the power of self-recognition. To be merely meat, to be meat all the way, would take away the ability to see, let alone represent one's self as such. Thus the announcement that one is meat, plastic and shit should be construed as a roundabout refusal to be just that.

Nevertheless, Genet was right in that representation generally wields a leaden touch. The artist peels off a likeness from the living and transfers it to the inanimate canvas, a surface that is as lifeless as the

14 Jean Genet, What remains of a Rembrandt torn into four equal pieces, and flushed down the toilet, Madras and New York, Hanuman Books, 1988, p. 43. 
corpse of an anatomy lesson. Perhaps a pause of queasy self-recognition crept upon Rembrandt as he painted surgeons around the dissecting table, in their midst a former person who is now meat, tendons, guts and, yes, paint streaks. Smears and daubs, after all, are what a portrait inescapably is. Could this be a clue to the oddest of Rembrandt's selfportraits, the one where he dangles a lifeless heron so that it blocks his face? When torn from the person and nailed on canvas, a likeness is a hunting trophy of sorts. Where, at any rate, is the ontological difference between a painting and a dead bird?

So a portraitist casts the evil eye, and the death-dealing glare is inherent in representation, whether it be the kindergartener's doodle or Ingres' exquisite sketches. Yet in the measure that the artist knows this, so he can also control it. An artist's job is to challenge the confines of his medium, not to plead captivity to its moral shortcomings. The odds are that an image will objectify; this is why there is grace and beauty in the portrait that succeeds in beating the odds.

Rembrandt returned often to the motif of corpses, perhaps because it was an opportunity to reflect on the danger of image-making. Perhaps he understood that portrait painting requires a touch as careful as the surgeon's own, a touch that remedies what even the surgeon cannot. For anatomists bow to the deadening process that runs from subject to object. Surgeons, after all, deal with nuts and bolts, whether they be dead or alive. The painter, by contrast, strives in the opposite direction, from object to subject. And when Rembrandt paints a corpse, it is to affirm its humanity. Such is the case of the stunning Anatomy of Dr Joan Deijman (1657), where Rembrandt puts before us an empty chest cavity from which the human heart is intolerably absent. It is the absence we are meant to endure. Call it a reverse portrait, a portrait of the aching absence of subjective life. Here, too, humanity proclaims its own demise, and thereby affirms itself.

This is why, in parting, we return to the portrait that first hypnotised us by its simple plea for solidarity. It is the unguarded confession, the poignant vulnerability of a Rembrandt portrait that moves us. It is the confession that the face in front of us is in need of us; that without us it is not a face but an anatomy. The humanity he or she has is the humanity we give them. The human face truly is tender clay: when 
we withdraw the feelers of recognition, it goes flat; it dulls, and dies. The portrait lives not by internal combustion but in the same way that the human face comes alive: in the degree to which it is encountered.

Rembrandt took on the work of building the human conversation and this is the work he passes on to us. How we pick it up from here- how long we remain alive to the call of these impossibly soulful eyesis a gauge of our commitment to the culture of the Town over that of the Court. 
This text is taken from Imaging Identity: Media, memory and portraiture in the digital age, edited by Melinda Hinkson, published 2016 by ANU Press, The Australian National University, Canberra, Australia. 